\title{
Reconnaissance study of glacier energy balance in North Greenland, 1993-94
}

\author{
Roger J. Braithwaite, ${ }^{1}$ Thomas Konzelmann, ${ }^{2}$ Christoph Marty, ${ }^{2}$ Ole B. Olesen ${ }^{3}$ \\ ${ }^{1}$ Department of Geography, University of Manchester, Manchester M13 9PL, England \\ ${ }^{2}$ Department of Geography, Swiss Federal Institute of Technology, CH-8057 Zürich, Switzerland \\ ${ }^{3}$ Geological Survey of Denmark and Greenland, DK-2400 Copenhagen NV, Denmark
}

\begin{abstract}
Reconnaissance energy-balance studies were made for the first time at two sites in North Greenland to compare with conditions in West Greenland. The field experiments were planned to save weight because it is expensive to operate in North Greenland. The larger energy components (incoming radiation and ablation) were measured for 55 days altogether, and the smaller components were evaluated by indirect methods, e.g. turbulent fluxes are calculated from air temperature, humidity and wind speed, to save the weight of instruments. The energy-balance model is "tuned" by choosing surface roughness and albedo to reduce the mean error between measured ablation and modelled daily melting. The error standard deviation for ablation is only $\pm 5 \mathrm{~kg} \mathrm{~m}^{-2} \mathrm{~d}^{-1}$, which is much lower than found in West Greenland, due to better instruments and modelling in the present study. Net radiation is the main energy source for melting in North Greenland but ablation is relatively low because sublimation and conductive-heat fluxes use energy that would otherwise be available for melting. There is a strong diurnal variation in ablation, mainly forced by variations in shortwave radiation and reinforced by nocturnal cooling of the ice surface by outgoing longwave radiation and sublimation. The model frequently predicts a frozen glacier surface at night even when air temperatures are positive.
\end{abstract}

\section{NOTATION}

CHF Conductive-heat flux into ice $\left(\mathrm{W} \mathrm{m}^{-2}\right)$

ERR Error in the energy balance $\left(\mathrm{W} \mathrm{m}^{-2}\right)$

LHF Turbulent latent-heat flux $\left(\mathrm{W} \mathrm{m}^{-2}\right)$

LWR Net longwave radiation $\left(\mathrm{W} \mathrm{m}^{-2}\right)$

MLT Daily melt energy $\left(\mathrm{W} \mathrm{m}^{2}\right)$

SHF Turbulent sensible-heat flux $\left(\mathrm{W} \mathrm{m}^{-2}\right)$

SWR Net shortwave radiation $\left(\mathrm{W} \mathrm{m}^{-2}\right)$

A Dimensionless bulk-transfer coefficient

$b \quad$ Atmospheric pressure $(\mathrm{Pa})$

$b_{0} \quad$ Standard atmospheric pressure $(101300 \mathrm{~Pa})$

$c_{\mathrm{p}} \quad$ Specific heat of air $\left(1005 \mathrm{~J} \mathrm{~kg}^{-1} \mathrm{~K}^{-1}\right)$

$e$
Vapour pressure $2 \mathrm{~m}$ over glacier surface $(\mathrm{Pa})$

Saturation vapour pressure at glacier surface $(611 \mathrm{~Pa})$

Gravitational acceleration $\left(9.81 \mathrm{~m} \mathrm{~s}^{-2}\right)$

von Kármán’s constant (0.41)

Thermal conductivity of ice $\left(2.1 \mathrm{~W} \mathrm{~m}^{-1} \mathrm{~K}^{-1}\right)$

Coefficient of eddy diffusivity $\left(\mathrm{m}^{2} \mathrm{~s}^{-1}\right)$

Latent heat of melting $\left(0.334 \mathrm{MJ} \mathrm{kg}^{-1}\right)$

Latent heat of vaporization (2.514 or $2.849 \mathrm{MJ} \mathrm{kg}^{-1}$ )

Conductive heat in the ice $\left(\mathrm{W} \mathrm{m}^{-2}\right)$

Air temperature $2 \mathrm{~m}$ over glacier (deg)

Pyrradiometer temperature $(\mathrm{K})$

Absolute air temperature $(\mathrm{K})$

Surface temperature of glacier (0 deg or $273.15 \mathrm{~K}$ )

Wind speed $2 \mathrm{~m}$ over glacier $\left(\mathrm{m} \mathrm{s}^{-1}\right)$

Friction velocity $\left(\mathrm{m} \mathrm{s}^{-1}\right)$

Depth below the ice surface $(\mathrm{m})$

Instrument height $(2 \mathrm{~m})$

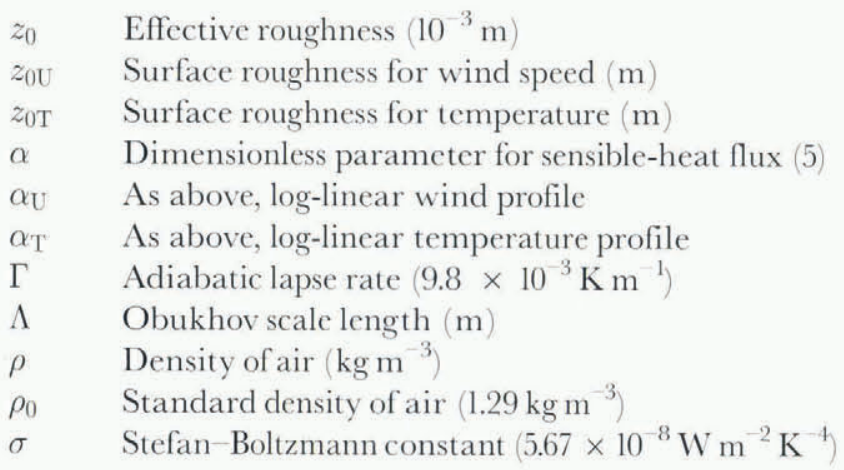

\section{INTRODUGTION}

Ablation-climate studies were made at two locations in North Greenland (Fig. 1 and Table 1) in the summers of 1993 and 1994. The studies were part of a 2 year programme on world sea-level changes supported by the European Union. North Greenland was chosen as the target because there is little information about ablation in the area, aside from a qualitative discussion by Fristrup (1951). The specific objectives of the studies were to collect daily ablation data and to compare ablation conditions with those found in West Greenland (Braithwaite and Olesen, 1989, 1990). For example, the best available model of the mass balance and dynamics of the Greenland ice sheet (Huybrechts and others, 1991) still uses positive degree-day factors found in West Greenland, representing an extrapolation to the whole ice sheet that may not be valid because ablation-climate conditions are not necessarily the same in all areas. 


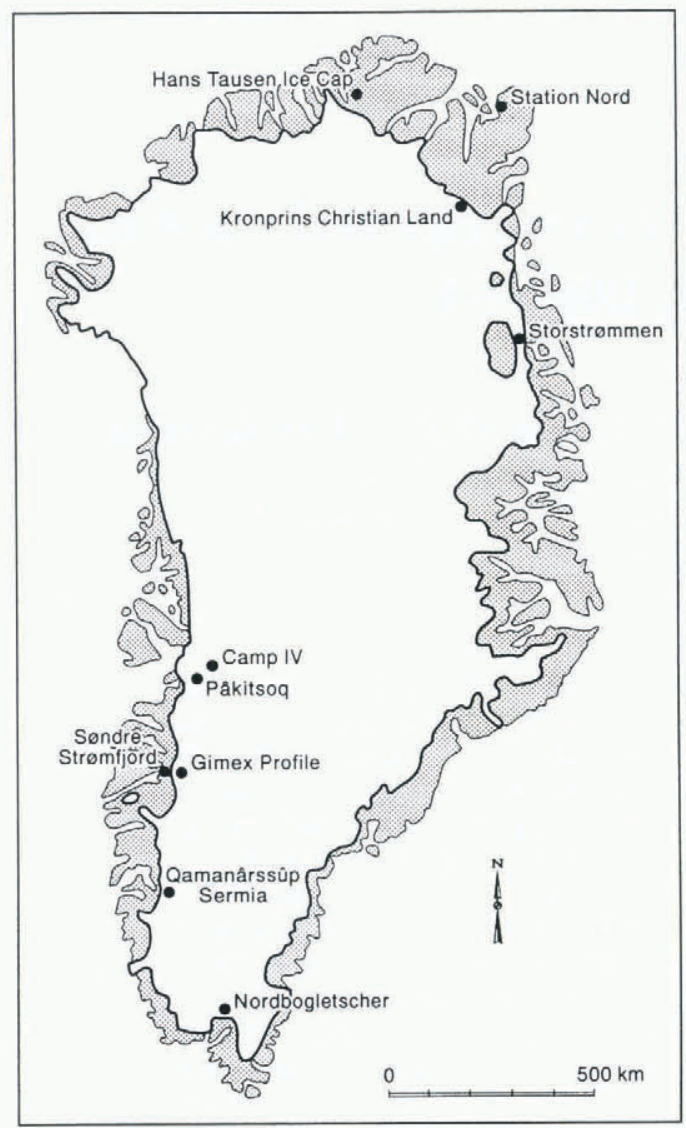

Fig. 1. Location map.

This is the first energy-balance study made in North Greenland. The field experiments were planned to save weight because it is very expensive to operate in this area. The basic approach is to measure the larger energy-balance components (radiation and ablation) as accurately as possible and to evaluate the smaller components (turbulent fluxes and conductive-heat flux into the ice) by indirect methods, requiring only light-weight equipment. By analogy with preliminary geological surveys, such an approach is termed a reconnaissance energy-balance study (Konzelmann and Braithwaite, 1995), in contrast to very comprehensive studies in West Greenland (Oerlemans and Vugts, 1993; Ohmura and others, 1994), which is more accessible.

\section{ENERGY BALANCE}

The energy required for melting MLT is provided by the energy balance:

$$
\mathrm{MLT}+\mathrm{CHF}=\mathrm{SWR}+\mathrm{LWR}+\mathrm{SHF}+\mathrm{LHF}+\mathrm{ERR}
$$

where CHF is the conductive-heat flux into the ice, SWR and LWR are the net short- and net longwave radiation fluxes, SHF and LHF are the turbulent sensible- and latentheat fluxes, and ERR is the total error in the energy-balance equation. Defined as above, ERR can be regarded as an unknown, extra source of energy that absorbs the errors in the other terms. The latent heat released by freezing of rain water on to the glacier surface is neglected as being very small compared with other terms.
Table 1. Periods of coverage and locations of the two ablationclimate datasets: Kronprins Christian Land (KPCL) and Hans Tausen Ice Cap (HTIC)

\begin{tabular}{lcc}
\hline & KPCL & HTIC \\
\hline Days & 20 & 35 \\
From & 8 July & 2 July \\
To & 27 July & 5 August \\
Year & 1993 & 1994 \\
Elevation ma.s.l. & 380 & 540 \\
Latitude & $79^{\circ} 54^{\prime} 43^{\prime \prime} \mathrm{N}$ & $82^{\circ} 49^{\prime} 26^{\prime \prime} \mathrm{N}$ \\
Longitude & $24^{\circ} 04^{\prime} 25^{\prime \prime} \mathrm{W}$ & $36^{\circ} 12^{\prime} 58^{\prime \prime} \mathrm{W}$ \\
& & \\
\hline
\end{tabular}

\section{ABLATION}

The lefthand side of the energy-balance Equation (1) involves melt energy rather than ablation but it is not possible to measure melt directly. What can be measured, although somewhat inaccurately, is the ablation, which is the net loss of material from the glacier surface by melt and vapour transfer together. Although the latter may involve a large energy flux, it only causes a very small mass change. For example, to anticipate the results of the present study, the largest daily value of latent-heat flux is $-71 \mathrm{~W} \mathrm{~m}^{-2}$, which gives a mass loss of only $2 \mathrm{~kg} \mathrm{~m}^{-2} \mathrm{~d}^{-1}$ by sublimation. Such a small change is not detectable as surface lowering and is negligible compared with the amount of melt. This is why this study, like others, treats ablation and melting as essentially identical in mass-balance terms and uses measured ablation to evaluate melt energy.

Daily measurements of ablation were made at two locations (Fig. 1): at the margin of the Greenland ice sheet in Kronprins Christian Land (KPCL) in 1993 and on an outlet glacier from the Hans Tausen Ice Cap (HTIC) in 1994.. Further details have been given by Braithwaite and others (in press).

Ablation was measured at ten stakes within an area of only about $100 \mathrm{~m}^{2}$, located beside the climate and radiation stations on the ice. The ten stakes were read daily at close to $19 \mathrm{~h} \mathrm{UTC}$ (about $17.15 \mathrm{~h}$ solar time in KPCL and $16.30 \mathrm{~h}$ solar time at HTIC). At both sites, ablation crust was ubiquitous and an alternation between a white crusty surface and blue ice, as described by Müller and Keeler (1969), was never observed. Data from the ten stakes were compared with each other to detect gross errors in the data, and erroneous data were discarded (one stake for KPCL 1993 and two stakes for HTIC 1994). The error standard deviation for daily ablation at the remaining stakes was about $\pm 5 \mathrm{~kg}$ $\mathrm{m}^{-2} \mathrm{~d}^{-1}$. This is further reduced to only about $\pm 2 \mathrm{~kg} \mathrm{~m}^{-2} \mathrm{~d}^{-1}$ by averaging over the available 9 or 8 stakes.

\section{ICE TEMPERATURE AND CONDUCTIVE-HEAT FLUX}

Although Braithwaite and Olesen (1990) neglected the conductive-heat flux into the ice in West Greenland, it was expected that this term would be significant in North Greenland. As only a rotary drill was available for the 1993 fieldwork, it was only possible to install thermistors into the ice to a depth of $3 \mathrm{~m}$ to evaluate the heat flux while in 1994 thermistors were installed to $10 \mathrm{~m}$ with a portable steam drill. 
Englacial temperatures were measured every day at both sites. The ice is very cold with the $0 \mathrm{deg}$ isotherm only about $0.2-0.3 \mathrm{~m}$ below the ice surface (even with the possible help of radiation warming of the thermistor cables) but ice temperatures rose by about $0.2-0.3 \mathrm{~K} \mathrm{~d}^{-1}$ within the top few metres.

The conductive-heat flux $Q$ at any depth in the ice is proportional to the vertical temperature gradient:

$$
Q=K(\delta T / \delta y)
$$

where $K$ is the thermal conductivity $\left(2.1 \mathrm{~W} \mathrm{~m}^{-1} \mathrm{~K}^{-1}\right)$ and $y$ is the depth below the ice surface. Note the different sign convention to Paterson (1994, p. 206), because we treat heat flux into the ice (away from the surface) as a heat sink.

Using Equation (2), the conductive-heat flux is calculated at depths midway between thermistors, whose initial depths are continually adjusted to take account of the surface lowering due to daily ablation. Results for the HTIC 1994 dataset are plotted in Figure 2 where the curve represents a second-degree polynomial, and the odd-looking point clusters are the result of many points lying close together, only separated by about $0.02 \mathrm{~m} \mathrm{~d}^{-1}$ due to ablation.

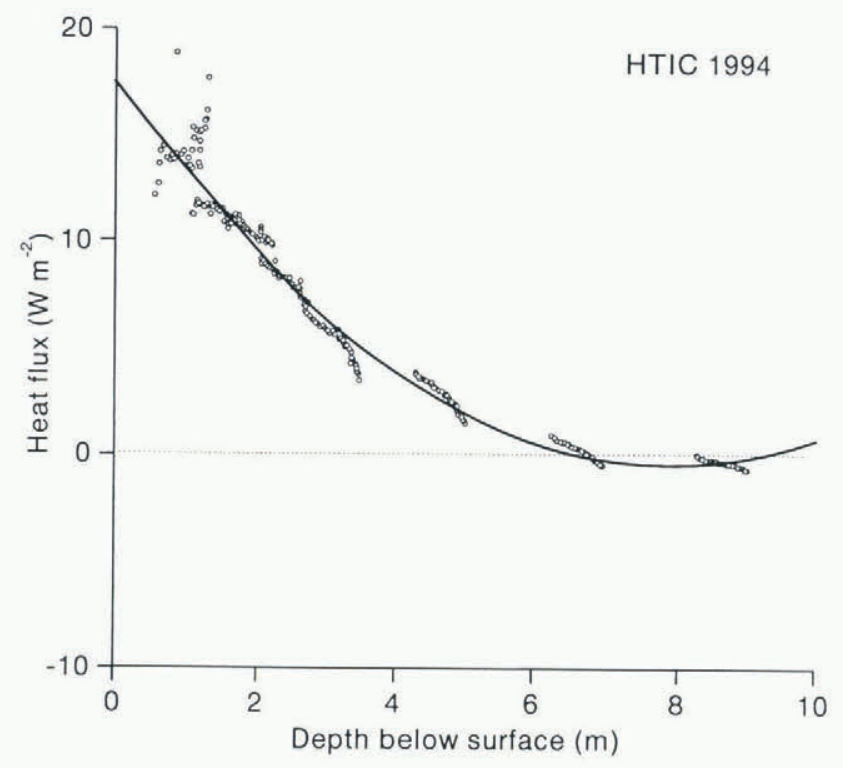

Fig. 2. Conductive-heat flux in the ice vs depth below the glacier surface, 2 July-5 August 1994 (days 183-217) at Hans Tausen Ice Cap ( HTIC).

The inflection in the curve at nearly $8 \mathrm{~m}$ below the surface is probably an artefact of the polynomial and is not important for the present discussion. On the other hand, the intercept of the curve with the vertical axis is an estimate of the mean conductive-heat flux at the glacier surface, i.c. $18 \mathrm{~W} \mathrm{~m}^{-2}$ in this case. Coincidentally, this is the same value found for KPCL 1993 (Konzelmann and Braithwaite, 1995). The latter assumed a linear correlation of heat flux with depth, but to less than $3 \mathrm{~m}$ below the glacier surface, and inspection of Figure 2 shows that heat flux for the HTIC 1994 dataset is also nearly linear within this depth range.

No doubt, the above method could be refined but it hardly seems worth it for present purposes. The conductive-heat flux CHF for both datasets is therefore assumed constant with a value of $18 \mathrm{~W} \mathrm{~m}^{-2}$.

\section{RADIATIVE FLUXES}

Due to the importance of radiative fluxes in the energy balance, priority was given to accurate measurements of incoming radiation.

Global radiation and all-wave incoming radiation were measured directly with a Swissteco SS-25 pyranometer and a Swissteco ST-25 pyrradiometer, respectively. For the KPCL 1993 experiment, these instruments were mounted on land beside the base camp, while they were mounted on the ice at the glacier station in the HTIC 1994 experiment. The 1993 configuration was chosen, because it was thought that it would be difficult to keep the instruments levelled if they were mounted on the ice. However, in 1994 the instruments were easily kept level by only small adjustments at least once a day. This is probably partly due to the low ablation rate, and partly due to the good design of the tripod instrument mounting.

The cosine error of the upfacing pyranometer was corrected for zenith angle $>70^{\circ}$ using a polynomial function whereby only part of the direct solar radiation is taken into account. Based on measurements made at ETH Camp (West Greenland) in June 1990, it was assumed that 70\% of global radiation is caused by direct solar radiation (Konzelmann and Ohmura, 1995). (Such an assumption is not needed if incoming global radiation is measured with two instruments, one with a shading ring and the other unshaded, but this was not done in the present study in the interests of saving weight by only using one instrument.)

The longwave incoming radiation was then calculated as the difference between the all-wave incoming radiation and the global radiation, and compensated for the emission loss of the instrument $\left(\sigma T_{\mathrm{i}}^{4}\right)$, where $\sigma$ is the Stefan-Boltzmann constant and $T_{\mathrm{i}}$ is the temperature of the pyrradiometer in Kelvin. There is a possible underestimation of the all-wave incoming radiation due to thermal convection (Ohmura and Gilgen, 1993) and the longwave incoming radiation was corrected accordingly. The remaining uncertainty in the incoming longwave radiation is estimated to be $\pm 10 \mathrm{~W} \mathrm{~m}^{-2}$ (DeLuisi and others, 1993). The longwave outgoing radiation $L^{\dagger}$ is calculated by:

$$
L^{\dagger}=\sigma T_{0}^{4}
$$

where $T_{0}$ is the temperature of the glacier surface $(273.15 \mathrm{~K}$ for melting ice).

Shortwave incoming radiation, together with reflected radiation, was also measured in both years at the glacier station with a Swissteco SW-2 two-component pyranometer (albedometer). The instrument was mounted on a survey tripod at a height of about $1.2 \mathrm{~m}$ and was relocated every few days to sample as many types of surface as possible. Figure 3 shows variations in daily albedo within the immediate area covered by stake measurements in the HTIC 1994 experiment. The very high albedo in the first sample (days 191-194 for "light hummock") was due to several days with snow, with maximum albedo 0.84 decaying to 0.59 . There were also traces of snow on days 183, 197 and 199, which correspond to small peaks in albedo. Otherwise, albedo varies greatly between about 0.3 and 0.5 , reinforcing the finding of Konzelmann and Braithwaite (1995) for the K PCL 1993 experiment. Bøggild and others (1996) have also measured larger-scale albedo variations from the ice margin, near to the site of the KPCL 1993 experiment, to the equilibrium line. An oblique air photograph of the field area clearly 


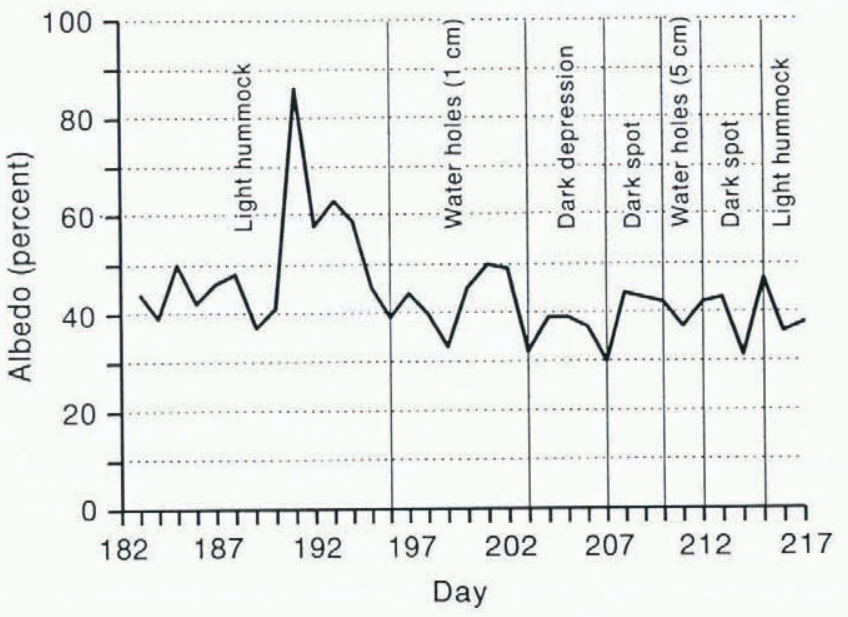

Fig. 3. Variations of daily albedo between different sites, 2 July-5 August 1994 (days 183-217) at Hans Tausen Ice Cap (HTIC).

showing albedo variations is on the front cover of Annals of Glaciology 23). Figure 3 undoubtedly shows albedo differences between different kinds of site but there are also large differences between different days at the same site. Aside from the effects of snow, albedo may also depend on whether the surface is frozen or melting. It would be interesting to operate both moveable and fixed albedo stations in a future experiment.

\section{TURBULENT FLUXES}

The vertical turbulent sensible-heat flux SHF is expressed in flux-gradient form as:

$$
\mathrm{SHF}=\rho c_{\mathrm{p}} K_{\mathrm{H}}(\mathrm{d} T / \mathrm{d} z-\Gamma)
$$

where $\rho$ is the density of air, $c_{\mathrm{p}}$ is the specific heat of air $\left(1005 \mathrm{~J} \mathrm{~kg}^{-1} \mathrm{~K}^{-1}\right), K_{\mathrm{H}}$ is the coefficient of turbulent diffusivity, $\mathrm{d} T / \mathrm{d} z$ is the vertical temperature gradient and $\Gamma$ is the adiabatic lapse rate. As the present paper only deals with the air layer close to the glacier surface (instrument height $2 \mathrm{~m}$ ) with large air-temperature gradients, $\Gamma$ is neglected compared with $\mathrm{d} T / \mathrm{d} z$. In the present paper, turbulent fluxes towards the glacier surface are positive.

Equation (4) can be reformulated in terms of simple data for wind speed and temperature following Ambach and Kirchlechner (1986) and Paterson (1994, p. 60-66):

$$
\mathrm{SHF}=\left(c_{\mathrm{p}} \rho_{0} / b_{0}\right) A b u\left(T-T_{0}\right)
$$

where $\rho_{0}$ is the density of air $\left(1.29 \mathrm{~kg} \mathrm{~m}^{-3}\right)$ at the standard atmospheric pressure $b_{0}(101300 \mathrm{~Pa}), A$ is a dimensionless transfer coefficient, $b$ is mean atmospheric pressure at the measuring site, and $u$ and $T$ are measured wind speed and air temperature at $2 \mathrm{~m}$ above the glacier surface.

Previous treatments (Braithwaite and Olesen, 1990; Konzelmann and Braithwaite, 1995) assumed logarithmic profiles of wind speed and temperature in the near-surface boundary layer, which are valid for neutral conditions. However, the approach is extended here to log-linear profiles, which are supposed to be more appropriate for the strong stability that can occur over a melting ice surface.
Under these conditions, the transfer coefficient is given by:

$$
A=\frac{k^{2}}{\left[\ln \left(z / z_{0 \mathrm{U}}\right)+\alpha_{\mathrm{U}}(z / \Lambda)\right]\left[\ln \left(z / z_{0 \mathrm{~T}}\right)+\alpha_{\mathrm{T}}(z / \Lambda)\right]}
$$

where $k$ is von Kármán's constant $(0.41), z$ is the instrument height $(2 \mathrm{~m}), z_{0 \mathrm{U}}$ and $z_{0 \mathrm{~T}}$ are surface roughness for wind speed and temperature, $\alpha_{\mathrm{U}}$ and $\alpha_{\mathrm{T}}$ are empirical parameters for the wind and temperature profiles, and $\Lambda$ is the scale height of Obukhov (1971):

$$
\Lambda=\frac{\rho c_{\mathrm{p}} u^{*^{3}} T_{\mathrm{K}}}{k g \mathrm{SHF}}
$$

where $T_{\mathrm{K}}$ is the absolute air temperature $(\mathrm{K}), g$ is the gravitational acceleration and $u^{*}$ is the friction velocity for the log-linear profile given by:

$$
u^{*}=\frac{k u}{\left[\ln \left(z / z_{0 \mathrm{U}}\right)+\alpha_{\mathrm{U}}(z / \Lambda)\right]} .
$$

The roughness lengths determine the magnitude of sensibleheat flux for neutral conditions, and the $\alpha$ parameters describe the reduction of sensible-heat flux with increasing stability. More research is needed to find the most appropriate values of these parameters to use in any particular situation. For the present study, Equation (6) is simplified as:

$$
A=\frac{k^{2}}{\left[\ln \left(z / z_{0}\right)+\alpha(z / \Lambda)\right]^{2}}
$$

where $z_{0}$ is the effective roughness for sensible-heat flux and $\alpha=\alpha_{\mathrm{U}}=\alpha_{\mathrm{T}}$. Morris and Harding (1991) assumed the same roughness lengths for wind and temperature profiles. There is, however, ample evidence that they are different (Sverdrup, 1935; Holmgren, 1971; Ambach and Kirchlechner, 1986; van den Broeke, 1996; Hock and Holmgren, 1996), and that roughness is not really constant with time either (Greuell and Konzelmann, 1994; Plüss and Mazzoni, 1994), but it is not clear what values should be used in a particular case (Braithwaite, 1995). The effective roughness $z_{0}$ is here defined such that Equation (9) gives the same $A$ value as Equation (6) and satisfies the inequality $z_{0 \mathrm{U}}>z_{0}>z_{0 \mathrm{~T}}$.

After some trial and error, a value of $10^{-3} \mathrm{~m}$ was adopted for $z_{0}$ over an ice surface (van de Wal and Russell, 1994; Bintanja, 1995; Konzelmann and Braithwaite, 1995). There is also an extensive literature on $\alpha$ (Garratt, 1992, p. 289) but this study follows Munro (1989) in assuming that $\alpha=5$ in stable conditions as proposed by Dyer (1974). An apparent difficulty is that the transfer coefficient, and hence the sensible-heat flux, uses the Obukhov length $\Lambda$ which, in turn, uses the sensible-heat flux. This vicious circle is avoided by an iterative procedure (Munro, 1989) whereby SHF is first calculated for $z / \Lambda=0$ (neutral case), then a new $\Lambda$ is calculated from SHF, and an updated SHF is calculated from the new $\Lambda$, the whole procedure being repeated 2-3 times until $\Lambda$ converges. Greuell and Konzelmann (1994) rejected this approach as "time consuming" but, to be fair, it does increase the total number of calculations in any modelling study by several times so that some workers may prefer a stability correction (without iteration) in terms of the Richardson number.

By analogy with the sensible-heat flux, the latent-heat flux is given by:

$$
\mathrm{LHF}=L_{\mathrm{v}}\left(0.623 \rho_{0} / b_{0}\right) A u\left(e-e_{0}\right)
$$

where $L_{\mathrm{v}}$ is the latent heat of vaporization, $e$ is the vapour pressure at height $z$ above the glacier surface and $e_{0}$ is the saturation vapour pressure at the glacier surface. The latter 
is a function of the surface temperature and is $611 \mathrm{~Pa}$ for a melting surface (Paterson, 1994, p. 65). We follow Ambach and Kirchlechner (1986), and Greuell and Konzelmann (1994), in distinguishing between condensation and sublimation, i.e. with latent heat $L_{\mathrm{v}}=2.514$ and $2.849 \mathrm{MJ} \mathrm{kg}^{-1}$, respectively. When $\left(e-e_{0}\right)$ is positive and $T_{0}=0 \mathrm{deg}$, water vapour condenses as liquid water on the melting glacier surface with $L_{\mathrm{v}}=2.514 \mathrm{MJ} \mathrm{kg}^{-1}$. When $\left(e-e_{0}\right)$ is negative, there is sublimation with $L_{\mathrm{v}}=2.849 \mathrm{MJ} \mathrm{kg}^{-1}$. Also, when $\left(e-e_{0}\right)$ is positive and $T_{0}<0 \mathrm{deg}$, there is condensation from vapour to solid ice with $L_{\mathrm{v}}=2.849 \mathrm{MJ} \mathrm{kg}^{-1}$.

\section{GALGULATION OF THE ENERGY BALANCE}

The full energy balance was calculated on an hour-to-hour basis. Aside from being physically more correct than a daily calculation, the hourly calculation of the turbulent fluxes has a hidden bonus. This is because the (unventilated) temperature sensors show clear signs of radiation heating: temperatures rise quickly if wind speeds drop below about $2 \mathrm{~m} \mathrm{~s}^{-1}$. This caused some concern until it was realized that, even if the temperature is erroneously high for a particular hour, it is multiplied by a correspondingly low wind speed for the same hour. The resulting error in the sensible-heat flux summed over any day is small because the largest contributions come from hours with high wind speeds.

For each hourly time-step, the glacier-surface temperature is initially assumed to be $273.15 \mathrm{~K}$ for calculation of longwave outgoing radiation, sensible-heat flux and latentheat flux, and a trial value of hourly ablation is calculated. If the trial value is negative, it is assumed that the glacier surface is frozen, and the surface temperature is reduced in the model by $0.1 \mathrm{~K}$ in successive steps until the trial ablation for the hour becomes zero. This occurs quite often in both datasets, even when the air temperature is positive, confirming that melting conditions cannot be assumed a priori or preset

Table 2. Calculated energy balance, 8-27 July 1993 (days 189-208) at Kronprins Christian Land (KPCL). Units are $W m^{-2}$

\begin{tabular}{|c|c|c|c|c|c|c|c|}
\hline Day & SWR & $L W R$ & SHF & $L H F$ & $E R R$ & $M L T$ & $C H F$ \\
\hline 189 & 186 & -52 & 85 & -41 & -35 & 126 & 18 \\
\hline 190 & 184 & -47 & 114 & -44 & 15 & 204 & 18 \\
\hline 191 & 169 & -44 & 112 & -27 & -5 & 188 & 18 \\
\hline 192 & 179 & -48 & 51 & -19 & -17 & 128 & 18 \\
\hline 193 & 150 & -38 & 60 & -28 & 1 & 128 & 18 \\
\hline 194 & 145 & -28 & 39 & -14 & -14 & 111 & 18 \\
\hline 195 & 176 & -42 & 94 & -32 & -6 & 173 & 18 \\
\hline 196 & 175 & -40 & 126 & -40 & 21 & 225 & 18 \\
\hline 197 & 174 & -39 & 127 & -53 & -11 & 180 & 18 \\
\hline 198 & 159 & -32 & 83 & -30 & -20 & 142 & 18 \\
\hline 199 & 170 & -34 & 65 & -20 & -1 & 163 & 18 \\
\hline 200 & 171 & -42 & 119 & -52 & 16 & 194 & 18 \\
\hline 201 & 163 & -46 & 127 & -54 & 32 & 204 & 18 \\
\hline 202 & 160 & -38 & 108 & -36 & 12 & 188 & 18 \\
\hline 203 & 160 & -43 & 96 & -41 & 3 & 157 & 18 \\
\hline 204 & 157 & -45 & 119 & -56 & 36 & 194 & 18 \\
\hline 205 & 158 & -49 & 82 & -46 & -6 & 122 & 18 \\
\hline 206 & 160 & -53 & 41 & -21 & 8 & 116 & 18 \\
\hline 207 & 159 & -56 & 44 & -28 & -4 & 97 & 18 \\
\hline$\underline{208}$ & $\underline{156}$ & -51 & 60 & -29 & $\underline{13}$ & $\underline{132}$ & $\underline{18}$ \\
\hline Mean & 166 & -43 & 88 & -36 & 2 & 159 & 18 \\
\hline$\underline{\text { S.D }}$ & \pm 11 & \pm 7 & \pm 31 & \pm 13 & $\underline{ \pm 18}$ & \pm 37 & \\
\hline
\end{tabular}

in models (Oerlemans, 1991; Van de Wal and Russell, 1994). Braithwaite and Olesen (1990) were ambiguous on this point as their paper implied that the surface temperature was preset at 0 deg but, in fact, a trial value of daily ablation is calculated to check for freezing temperatures. Kuhn (1987) suggested that melting conditions can prevail over a wide range of air temperatures, both negative and positive, but the present results suggest a definite tendency towards a frozen ice surface while air temperatures are still positive.

The hourly values of the computed energy balance are summed into daily totals in Tables 2 and 3. The day refers to the 24 hour period from $20 \mathrm{~h}$ UTC on one day to $19 \mathrm{~h}$ UTC on the following day, because daily ablation is measured between these times. The error in the daily energy balance is then calculated as the difference between measured daily ablation and modelled daily ablation.

\section{SENSITIVITY OF THE MODEL TO ASSUMPTIONS}

The error in the calculated ablation can be used to judge the sensitivity of the model to different assumptions about roughness, albedo and the effect of stability (Table 4).

For KPCL 1993, a roughness of $10^{-3} \mathrm{~m}$ and an albedo of 0.48 gives a smaller error than the other assumptions. How-

Table 3. Calculated energy balance, 2 July-5 August 1994 (days 183-217), at Hans Tausen Ice Cap (HTIC). Units are $\mathrm{Wm}^{-2}$

\begin{tabular}{|c|c|c|c|c|c|c|c|}
\hline Day & $S W R$ & $L W R$ & $S H F$ & LHF & $E R R$ & $M L T$ & $\mathrm{CHF}$ \\
\hline 183 & 75 & -11 & 7 & -8 & -13 & 33 & 18 \\
\hline 184 & 90 & -9 & 14 & -11 & 6 & 73 & 18 \\
\hline $19^{-}$ & 133 & -27 & 14 & -12 & -24 & 66 & 18 \\
\hline 186 & 100 & -21 & 31 & -70 & -2 & 20 & 18 \\
\hline 187 & 97 & -23 & 33 & -71 & 3 & 20 & 18 \\
\hline 188 & 121 & -30 & 27 & -53 & -16 & 31 & 18 \\
\hline 189 & 94 & -17 & 60 & -37 & 46 & 129 & 18 \\
\hline 190 & 93 & -14 & 43 & -45 & 13 & 72 & 18 \\
\hline 191 & 58 & -6 & 0 & -11 & -28 & -5 & 18 \\
\hline 192 & 94 & -29 & 31 & -71 & 3 & 9 & 18 \\
\hline 193 & 105 & -31 & 4 & -34 & -19 & 7 & 18 \\
\hline 194 & 164 & -55 & 10 & -6 & -61 & 35 & 18 \\
\hline 195 & 173 & -60 & 48 & -9 & 6 & 140 & 18 \\
\hline 196 & 132 & -36 & 14 & -2 & -6 & 85 & 18 \\
\hline 197 & 109 & -44 & 9 & -13 & 6 & 50 & 18 \\
\hline 198 & 109 & -55 & 12 & -13 & 17 & 52 & 18 \\
\hline 199 & 54 & -23 & 7 & -11 & -8 & 2 & 18 \\
\hline 200 & 114 & -18 & 11 & -11 & -2 & 76 & 18 \\
\hline 201 & 157 & -58 & 22 & -22 & -12 & 70 & 18 \\
\hline 202 & 167 & -54 & 30 & -25 & -15 & 85 & 18 \\
\hline 203 & 119 & -7 & 35 & -13 & 28 & 144 & 18 \\
\hline 204 & 157 & -42 & 53 & -13 & 6 & 144 & 18 \\
\hline 205 & 143 & -36 & 35 & -11 & 30 & 144 & 18 \\
\hline 206 & 138 & -38 & 38 & -19 & 12 & 113 & 18 \\
\hline 207 & 83 & -9 & 21 & -8 & 13 & 83 & 18 \\
\hline 208 & 160 & -62 & 25 & -20 & -4 & 81 & 18 \\
\hline 209 & 146 & -50 & 34 & -15 & 4 & 100 & 18 \\
\hline 210 & 152 & -48 & 36 & -15 & 19 & 126 & 18 \\
\hline 211 & 150 & -46 & 67 & -23 & 3 & 133 & 18 \\
\hline 212 & 148 & -47 & 52 & -17 & 12 & 131 & 18 \\
\hline 213 & 132 & -46 & 26 & -12 & 1 & 83 & 18 \\
\hline 214 & 79 & -19 & 19 & -32 & -7 & 22 & 18 \\
\hline 215 & 71 & -15 & 15 & -20 & -3 & 31 & 18 \\
\hline 216 & 67 & -9 & 26 & -19 & 44 & 92 & 18 \\
\hline 217 & 60 & -10 & $\underline{41}$ & $\underline{-56}$ & -3 & 15 & 18 \\
\hline Mean & 116 & -32 & 27 & -24 & 1 & 71 & 18 \\
\hline S.D. & \pm 35 & \pm 18 & \pm 17 & $\underline{ \pm 19}$ & \pm 20 & \pm 47 & \\
\hline
\end{tabular}


Table 4. Error in calculating melt energy as a function of stability, surface roughness and albedo for two ablation-climate datasets: Kronprins Christian Land (KPCL) and Hans Tausen Ice Cap (HTIC). Units are $\mathrm{Wm}^{-2}$

\begin{tabular}{|c|c|c|}
\hline & $K P C L$ & HTIC \\
\hline Days & 20 & 35 \\
\hline Year & 1993 & 1994 \\
\hline \multicolumn{3}{|c|}{ Roughness $\left(\times 10^{-3} \mathrm{~m}\right)^{1}$} \\
\hline 0.5 & $10.1 \pm 19.2$ & $2.6 \pm 21.2$ \\
\hline 1.0 & $1.8 \pm 17.6$ & $1.4 \pm 21.1$ \\
\hline 2.0 & $-9.1 \pm 16.5$ & $-0.2 \pm 19.9$ \\
\hline \multicolumn{3}{|l|}{ Ice albedo ${ }^{2}$} \\
\hline 0.43 & $-14.1 \pm 17.9$ & $-8.7 \pm 20.6$ \\
\hline 0.48 & $1.8 \pm 17.6$ & $1.4 \pm 21.1$ \\
\hline 0.53 & $17.7 \pm 17.5$ & $11.4 \pm 20.5$ \\
\hline \multicolumn{3}{|c|}{ Stability effect ${ }^{1,2}$} \\
\hline Off & $-2.9 \pm 18.2$ & $-3.9 \pm 19.2$ \\
\hline On & $1.8 \pm 17.6$ & $1.4 \pm 21.1$ \\
\hline
\end{tabular}

${ }^{1}$ Ice albedo $=0.48 . \quad{ }^{2}$ Roughness $=1 \times 10^{-3} \mathrm{~m}$.

ever, for HTIC 1994, the error is not very sensitive to different choices of roughness because the sensible- and latentheat fluxes are of roughly equal and opposite magnitudes. The weighted average of the albedo measurements in Figure 3 for HTIC 1994, excluding the few days with snow, is about 0.43 but a model ice albedo of 0.48 gives a lower error for HTIC 1994 as well as for KPCL 1993.

The log-linear profile need not be true for real glaciers and ice sheets with sloping and inhomogenous surfaces (Hock and Holmgren, 1996), and should not be applied blindly. Extra calculations of the turbulent fluxes were therefore made without taking account of stability, i.e. assuming logarithmic profiles instead of log-linear profiles, and the resulting errors are given in Table 4 for the case "Stability effect Off". In both datasets, the mean errors are slightly more negative than in the case of "Stability effect On" but this can be offset again by choosing a smaller effective roughness. The effect of stability is therefore fairly small and the correctness of the stability assumption is not unequivocally demonstrated by this sensitivity analysis. The reason is probably that neither of the datasets involves very strong stability. This point is illustrated in Figure 4, which shows the exchange coefficient $A$ as a function of wind speed

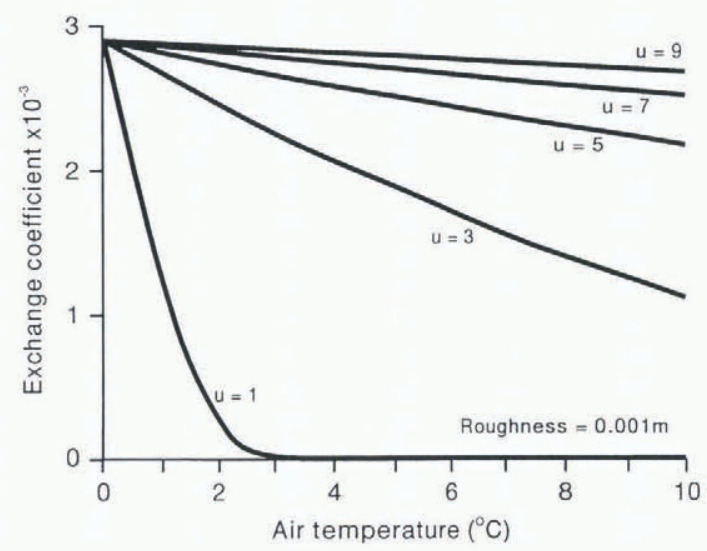

Fig. 4. Dimensionless exchange coefficient for sensible-heat flux. Temperature and wind at $2 \mathrm{~m}$ above melting glacier surface. $u$ and air temperature (both at $2 \mathrm{~m}$ above a melting surface). For high wind speeds and the relatively low air temperatures that prevailed in both datasets, the exchange coefficient is quite high and fairly constant.

The process of choosing model parameters to fit the data, i.e. "model tuning" to find the desired values of effective roughness and albedo, is not one to be undertaken lightly. For example, if the model is incorrectly specified, or if the data are wildly inaccurate, the model parameters found by tuning will be wrong. However, in the present case, the indicated values of both the effective roughness and albedo are highly plausible. For example, an effective roughness $z_{0}$ of $10^{-3} \mathrm{~m}$ is consistent with the larger $z_{0 \mathrm{U}}$ values reported in the literature (Kuhn, 1979; Morris, 1989; van den Broeke, 1996), if it is also combined with much smaller $z_{0 \mathrm{~T}}$ values in agreement with Sverdrup (1935), Holmgren (1971), Ambach and Kirchlechner (1986), van den Broeke (1996) and Hock and Holmgren (1996). By the same token, an albedo of 0.48 is within the range of albedo values measured at both sites and may well be the "most representative" value.

\section{ABLATION VARIATIONS}

The error in the calculated daily energy balance reflects errors in the data and in the modelling, and represents the accuracy with which ablation or melting can be calculated.

The small mean values of the errors in Tables 2 and 3 have no special significance because surface roughness and albedo values in the model are chosen to make the mean error small, i.e. by tuning the model (Table 4). The standard deviations of the errors are also small and these are not directly affected by the tuning. For example, there is a strong correlation between measured and calculated ablation (Fig. 5) with an error standard deviation of only about $\pm 5 \mathrm{~kg} \mathrm{~m}^{-2}$ $\mathrm{d}^{-1}$. This is a lot lower than the $\pm 14-19 \mathrm{~kg} \mathrm{~m}^{-2} \mathrm{~d}^{-1}$ achieved in West Greenland (Braithwaite and Olesen, 1990). The reasons for the lower errors are discussed in the following section, but for the present it is enough that the error standard deviations are small compared with ablation variations. However, as should be clear from Figure 5, some

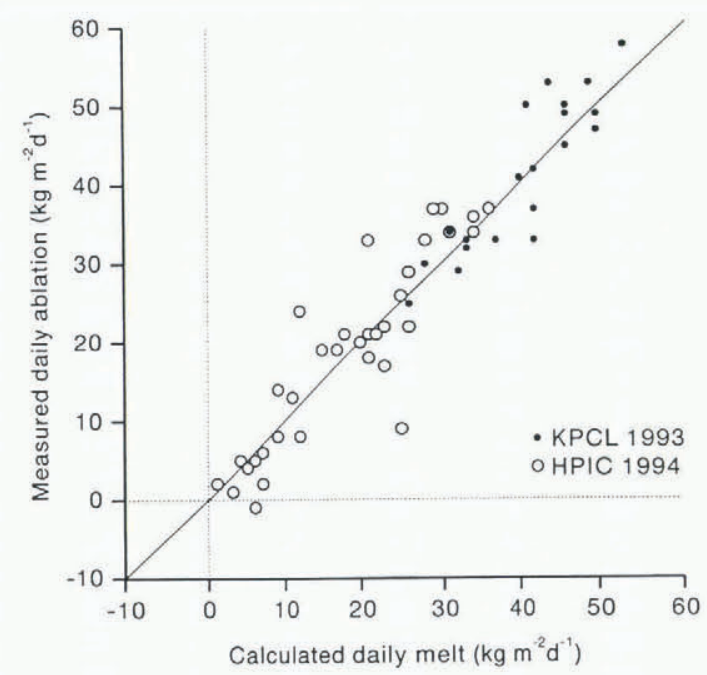

Fig. 5. Measured daily ablation and daily ablation calculated from the energy balance for Kronprins Christian Land (KPCL) and Hans Tausen Ice Cap (HTIC). Periods are 8-27 July 1993 at KPCL and 2 July-5 August at HTIC. 
very large daily errors can occur, which seem too large to be measurement errors and must be model errors. There is therefore still room for improving the model.

In Figure 6 the melt energy is compared with net radiation (the sum of short- and longwave radiation) and the total turbulence (the sum of sensible- and latent-heat fluxes). It is clear that ablation was generally high for KPCL 1993 because of high net radiation and high turbulence. However, day-to-day variations in net radiation are rather small and the ablation is mainly controlled by variations in turbulence, in agreement with Braithwaite (1981). By contrast, ablation was generally low for HTIC 1994, because both net radiation and turbulence are low, and the latter is even negative for several periods such that the net contribution of turbulence to melt energy is rather small. However, day-today variations in ablation for HTIC 1994 are in step with both turbulence and net radiation. For example, the ablation minimum at day 191 is caused by high surface albedo due to fresh snow that coincides with low temperature.

Although ablation is only measured on a daily basis, the diurnal variation in melt energy can be calculated with the energy-balance model (Fig. 6). Despite the high latitude with 24 hours daylight, there is a strong diurnal variation at both sites, which is mainly forced by variations in short-
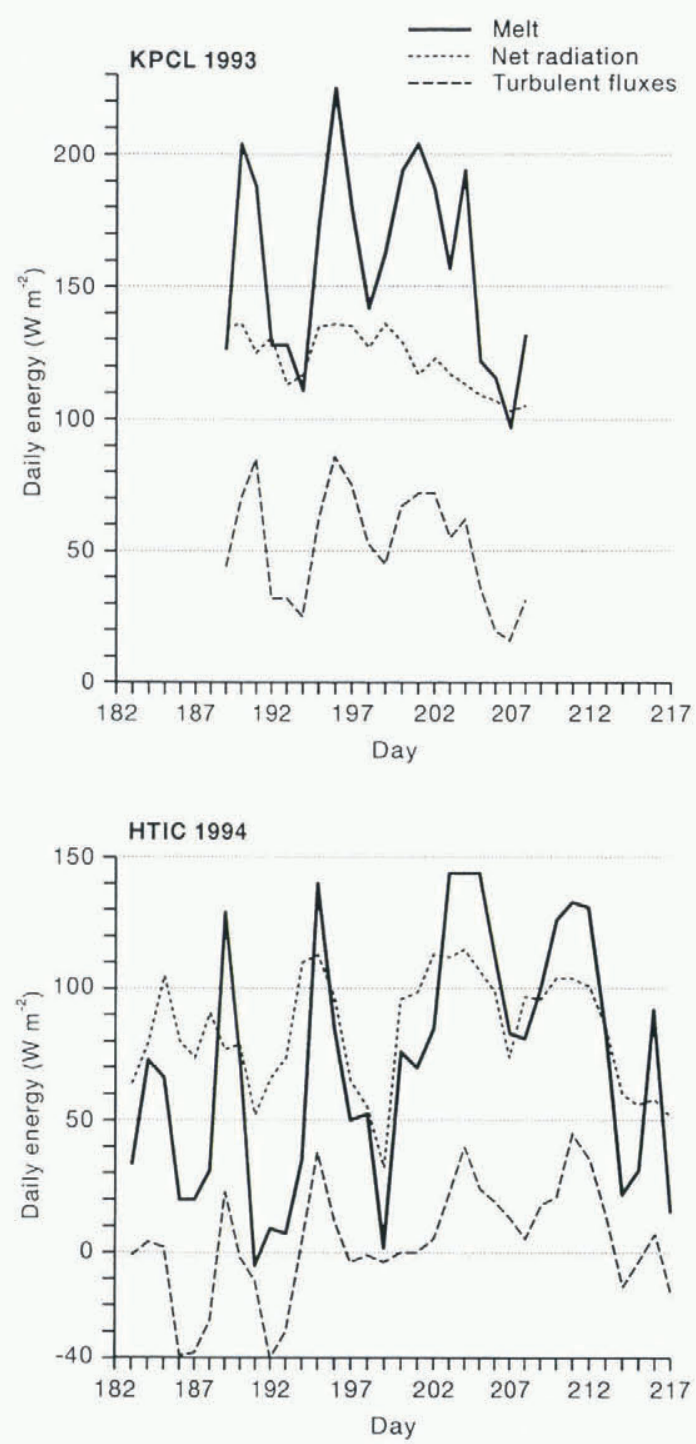

Fig. 6. Variations of daily melt energy, net radiation and turbulent fluxes for Kronprins Christian Land (KPCL) and Hans Tausen Ice Cap (HTIC). Periods are 8-27 July 1993 at KPCL and 2 July-5 August at HTIC. wave radiation and reinforced by nocturnal cooling of the ice surface by outgoing longwave radiation and sublimation. The energy-balance model frequently predicts a frozen glacier surface at night even when air temperatures are positive. This explains the frequent observation of ice in waterfilled cryoconite holes until well into the day (the ice is usually above the water level in the holes, which has presumably dropped since the ice formed).

The displacement of the maxima in Figure 7 is mainly caused by the difference in solar noon due to the differing longitude of the two sites, i.e. about 13.40 and 14.30 UTC for KPCL and HTIC, respectively.

\section{COMPARISON WITH WEST GREENLAND}

The energy-balance studies in North Greenland are compared in Tables 5 and 6 with two earlier studies from West Greenland (Braithwaite and Olesen, 1990). Differences reflect both different methods (Table 5) and different glacier-climate conditions (Table 6). The North Greenland data essentially cover July, while the West Greenland studies extend over June-August. The large sample sizes for the West Greenland studies represent overkill (there was a strong political motive to keep the data collection going as part of investigations for hydro-electric power in the late 1970 s and early 1980s) but it is impossible to claim that the shorter North Greenland studies are completely representative: the ideal would be measurements over several seasons.

The albedo is higher for the North Greenland cases (Table 4) than for those assumed for West Greenland. No explanation for this can be given here, but Bøggild and others (1996) and Cutler and Munro (1996) suggested that albedo is mainly controlled by debris inclusions in the ice, and the matter certainly deserves further attention. The apparently higher surface roughness for the North Greenland cases is not significant because different wind and temperature profiles are used. The log-linear profile for KPCL and HTIC leads to reduced sensible-heat flux under stable condition but this could be offset again by choosing a higher effective roughness (Braithwaite, 1995). Judged subjectively, the local topography at Qamanârssûp sermia (QAM) was the roughest of the four cases and Hans Tausen Ice Cap (HTIC) the smoothest.

The errors in the energy balance are much lower for the

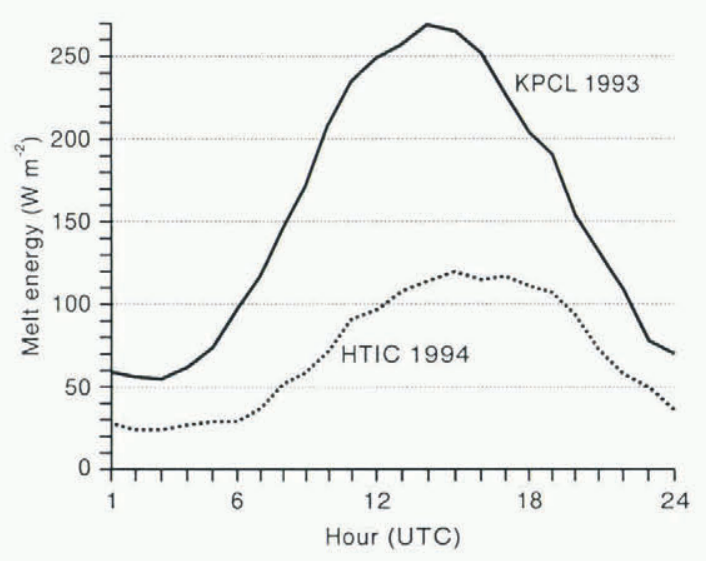

Fig. 7. Diurnal variation in mean melt energy for Kronprins Christian Land (KPCL) and Hans Tausen Ice Cap (HTIC). Periods are 8-27 fuly 1993 at KPCL and 2 July-5 August at HTIC. 
Table 5. Methodology of energy-balance studies at four sites in Greenland: Nordbogletscher (NBG), Qamanârssûp sermia (QAM), Kronprins Christian Land (KPCL) and Hans Tausen Ice Cap (HTIC)

\begin{tabular}{lcc}
\hline & $N B G+Q A M$ & $K P C L+H T I C$ \\
\hline Energy-balance calculation & Daily & Hourly \\
Surface-temperature check & Daily & Hourly \\
Shortwave radiation & Actinograph & Pyranometer \\
Longwave radiation & Estimated & Pyrradiometer \\
Assumed ice albedo & 0.3 & 0.48 \\
Assumed $u$ and $T$ profiles & Logarithmic & Log-linear \\
Assumed roughness $(\mathrm{m})$ & 0.00017 & 0.001 \\
Number of ablation stakes & 3 & 10 \\
Error $\left(\mathrm{W} \mathrm{m}^{-2}\right.$ ) & $\pm 53-73$ & $\pm 18-20$ \\
& & \\
\hline
\end{tabular}

North Greenland cases (KPCL and HTIC) than for the West Greenland sites (NBG and QAM). From Table 5, there could be several reasons for the greater accuracy. First, the energy-balance calculation is made every hour, including the check on surface temperature that actually shows a surprisingly large number of cases with a frozen surface while air temperatures are still positive. This effect is largely missed if the energy balance is calculated with daily data as in West Greenland (the data collections in the latter case were based on old-fashioned recorders and only analysed on a daily basis while the present study uses modern data loggers). Secondly, shortwave radiation is measured with better instruments (pyranometers), and longwave radiation is based on measurements (pyrradiometers) rather than estimated. Thirdly, the ablation measurements in North Greenland are made with a larger number of stakes (ten instead of three) with a careful check for errors (Braithwaite and others, in press).

The highest amount of net radiation was for the KPCL dataset (Table 6) but this mainly reflects a long period of fine and clear weather due to an anticyclone over Greenland (Geb and Naujokat, 1993) and may not be entirely typical. Otherwise, Qamanârssûp sermia (QAM) has higher net radiation than Nordbogletscher (NBG), because of a slightly more continental climate. Overall, net radiation accounts for $58-75 \%$ of the total energy sources for the four sites.

The KPCL dataset (Table 6) has the largest sensibleheat flux, which is mainly due to the predominance of high wind speeds as air temperatures are fairly low. By comparison, Qamanârssûp sermia (QAM) has high sensible-heat flux due to both high wind speed and temperature. Sensible-heat flux was low at HTIC because both wind speed and temperature are low.

The relative roles of condensation and sublimation in the melt process has long been a point of controversy in the snowmelt literature, and is important, because the first is a source of melt energy while the second takes energy that would otherwise be available for melting. In the 1930s, François Matthes stressed the importance of sublimation for snow ablation, as quoted and supported by Beaty (1975), but this has been denied by Sharp (1951). For the West Greenland sites, condensation and sublimation on average nearly balance (with some large daily latent-heat fluxes of both signs) compared with large sublimation at the North Greenland sites, amounting to 17 and $21 \%$ of the total energy sinks. In percentage terms, the latter agrees well with measurements in northeast Greenland (Lister and Taylor, 1961),
Table 6. Mean energy balance at four sites in Greenland: Nordbogletscher (NBG), Qamanârssûp sermia (QAM), Kronprins Christian Land (KPCL) and Hans Tausen Ice Cap (HTIC)

\begin{tabular}{|c|c|c|c|c|}
\hline & $\mathcal{N B G}$ & $Q A M$ & KPCL & $H T I C$ \\
\hline Latitude ${ }^{\circ} \mathrm{N}$ & 61 & 64 & 80 & 83 \\
\hline Days & 415 & 512 & 20 & 35 \\
\hline Altitude ( $\mathrm{m}$ a.s.l.) & 880 & 790 & 380 & 540 \\
\hline Air temperature (deg) & 3.7 & 5.0 & 4.2 & 3.0 \\
\hline Wind speed $\left(\mathrm{ms}^{-1}\right)$ & 3.3 & 4.8 & 6.2 & 3.6 \\
\hline \multicolumn{5}{|l|}{ Heat sources $\left(\mathrm{Wm}^{-2}\right)$} \\
\hline Net radiation & 79 & 103 & 122 & 84 \\
\hline Sensible heat & 32 & 62 & 88 & 27 \\
\hline Condensation & 7 & 9 & 0 & 0 \\
\hline Error & 2 & 2 & 2 & 1 \\
\hline$\overline{\text { Total sources }}$ & $\overline{116}$ & $\overline{176}$ & $\overline{212}$ & $\overline{112}$ \\
\hline \multicolumn{5}{|l|}{ Heat sinks $\left(\mathrm{W} \mathrm{m}^{-2}\right)$} \\
\hline Melting & 111 & 161 & 158 & 71 \\
\hline Conductive heat & - & - & 18 & 18 \\
\hline Sublimation & 5 & 15 & 36 & 24 \\
\hline Total sinks & $\overline{116}$ & $\overline{176}$ & $\overline{212}$ & $\overline{112}$ \\
\hline
\end{tabular}

showing the dominance of sublimation, and qualitatively with a report from Peary Land, North Greenland (Fristrup, 1951). The predominance of sublimation over condensation is a general characteristic of ablation at lower temperatures, e.g. early in the melt season for all types of glacier (Wallén, 1948) or in more continental conditions (Ohmura and others, 1990; Ohno and others, 1992). The ultimate expression of the dominance of sublimation over melting in the ablation process is reached in the "blue ice" areas of the Antarctic where there is no melting (Bintanja and van den Broeke, 1994).

The ablation energy is fairly low for the North Greenland sites if one takes account of their lower elevations compared to the West Greenland sites. Conductive-heat flux in West Greenland must be quite low but it is probably incorrect to neglect it completely as in Table 6 . By contrast, conductive-heat flux accounts for 8 and $16 \%$ of the total heat source at the North Greenland sites. The overall impression is that ablation in North Greenland is relatively low, because both sublimation and conductive-heat flux use energy that would otherwise be available for melting.

\section{CONCLUSIONS}

The energy-balance model can be "tuned" by choosing surface roughness and albedo to reduce the error between observed and calculated daily ablation, and this is achieved with an effective roughness of $10^{-3} \mathrm{~m}$ and an albedo of 0.48 .

Ablation calculated with the energy-balance model is strongly correlated with measured ablation with an error standard deviation of only about $\pm 5 \mathrm{~kg} \mathrm{~m}^{-2} \mathrm{~d}^{-1}$ (equivalent to $\pm 18-20 \mathrm{~W} \mathrm{~m}^{-2}$ in energy terms). This is a lot lower than achieved in earlier studies in West Greenland, due to better instruments and better modelling in the present study.

Radiation is the main energy source in North Greenland and ablation is relatively low because sublimation and conductive-heat fluxes use energy that would otherwise be available for melting.

The energy-balance model predicts a strong diurnal var- 
iation in ablation, mainly forced by variations in incoming shortwave radiation and reinforced by nocturnal cooling of the ice surface by outgoing longwave radiation and sublimation. There is frequently a frozen glacier surface at night even when air temperatures are positive.

\section{ACKNOWLEDGEMENTS}

This paper is published by permission of the Geological Survey of Denmark and Greenland (GEUS, formerly GGU). Fieldwork in both 1993 and 1994 was supported by the European Union under contract No. EV5V-CT91-0051, co-ordinated by the Climate Research Unit, University of East Anglia. Additional support for the 1994 work on the Hans Tausen Ice Cap was provided by the Nordic Council under a contract to N. Reeh, Danish Polar Centre, Copenhagen. Logistic support in both years was supplied by GGU's base camp at Centrum So, Kronprins Christian Land, lead by GGU Statsgeolog N. Henriksen. K. Schroff (Department of Geography, Swiss Federal Institute of Technology) prepared the radiation instruments, and Professor A. Ohmura and R. Hock, of the same institute, commented on the first draft of this paper.

\section{REFERENCES}

Ambach, W. and P. Kirchlechner. 1986. Nomographs for the determination of meltwater from ice- and snow surfaces by sensible and latent heat. Wetter Leben, 38 4), 181-189.

Beaty, C. B. 1975. Sublimation or melting: observations from the White Mountains, California and Nevada, U.S.A. F. Glaciol., 14 (71), 275286.

Bintanja, R. 1995. The local surface energy balance of the Ecology Glacier, King George Island, Antarctica: measurements and modelling. Antarcl. Sci., 7 (3), 315-325.

Bintanja, R. and M. R. van den Broeke. 1994. Local climate, circulation and surface-energy balance of an Antarctic blue-ice area. Ann. Glaciol., $20,160-168$.

Boggild, C. E., H. Oerter and T. Tukiainen. 1996. Increased ablation of Wisconsin ice in eastern North Greenland: observations and modelling. Ann. Glaciol., 23, 144-148.

Braithwaite, R.J. 1981. On glacier energy balance, ablation, and air temperature. J. Glaciol., 27 (97), 381-391.

Braithwaite, R.J. 1995. Acrodynamic stability and turbulent sensible-heat flux over a melting ice surface, the Greenland ice sheet. $\overline{7}$. Glaciol., 41 (139), 562-571.

Braithwaite, R.J. and O. B. Olesen. 1989. Calculation of glacier ablation from air temperature, West Greenland. In Oerlemans, J., ed. Glacier fluctuations and climatic change. Dordrecht, etc., Kluwer Academic Publishers, 219-233.

Braithwaite, R. J. and O. B. Olesen. 1990. A simple energy-balance model to calculate ice ablation at the margin of the Greenland ice sheet. J. Glaciol., 36(123), 222-228.

Braithwaite, R. J., T. Konzelmann, C. Marty and O. B. Olesen. In press. Erros in daily ablation measurements in North Greenland, 1993-94, and their implications for glacier-climate studies. j. Glaciol..

Cutler, P. M. and D. S. Munro. 1996. Visible and near-infrared reflectivity during the ablation period on Peyto Glacier, Alberta, Canada. J. Glaciol., 42 (141), $333-340$.

DeLuisi, J., K. Dehne, R. Vogt, T. Konzelmann and A. Ohmura. 1993. First results of the baseline surface radiation network (BSRN) broadband infrared radiometer intercomparison at FIRE II. In Keevallik, S. and O. Kärner, eds. Current problems in atmospheric radiation. Hampton, VA, A. Deepak Publishing, 559-564.

Dyer, A.J. 1974. A review of flux-profile relationships. Boundary-Layer Meteorol., 7, 363-372.

Fristrup, B. 1951. Climate and glaciology of Peary Land, North Greenland. International Association of Scientific Hydrology Publication 32, (General Assembly of Brussels 1951 - Snow and Ice), Vol. 1, 185-193.

Garratt, J. R. 1992. The atmospheric boundary layer. Cambridge, Cambridge University Press.
Geb, M. and B. Naujokat. 1993. Nordhemisphärischer Klimabericht zum Juni/ Juli/August 1993. Berlin, Freie Universität Berlin. Institut für Meteorologic. (Beilage zur Berliner Wetterkarte.)

Greuell, J.W. and T. Konzelmann. 1994. Numerical modeling of the energy balance and the englacial temperature of the Greenland ice sheet: calculations for the ETH-Camp location (West Greenland, $1155 \mathrm{~m}$ a.s.l.). Global and Planetary Change, $9(1-2), 91-114$.

Hock, R. and B. Holmgren. 1996. Some aspects of energy balance and ablation of Storglaciären, northern Sweden. Geogr. Ann., 78A 2-3), 121-131.

Holmgren, B. 1971. Climate and energy exchange on a sub-polar ice cap in summer. Arctic Institute of North America Devon Island Expedition 1961-1963. Part C. On the katabatic winds over the north-west slope of the ice cap. Variations of the surface roughness. Uppsala, Uppsala Universitet. Meteorologiska Institutionen. (Meddelande 109.)

Huybrechts, P., A. Letréguilly and N. Reeh. 1991. The Greenland ice sheet and greenhouse warming. Global and Planetary Change, 3 (4), 399-412.

Konzelmann, T. and R.J. Braithwaite. 1995. Variations of ablation, albedo and energy balance at the margin of the Greenland ice sheet, Kronprins Christian Land, eastern north Greenland. J. Glaciol., 41 (137), 174-182.

Konzelmann, T. and A. Ohmura. 1995. Radiative fluxes and their impact on the energy balance of the Greenland ice sheet. f. Glaciol., 41 (139), 490-502.

Kuhn, M. 1979. On the computation of heat transfer coefficients from energy-balance gradients on a glacier. f. Glaciol., 22 (87), 263-272.

Kuhn, M. 1987. Micro-meteorological conditions for snow melt. 7. Glaciol., $33(113), 24-26$.

Lister, H. and P. F. Taylor. 1961. Heat balance and ablation on an Arctic glacier. Medd. Gronl., 158 (7).

Morris, E. M. 1989. Turbulent transfer over snow and ice. J. Hydrol., 105 (34), 205-223.

Morris, E. M. and R. J. Harding. 1991. Parameterization of turbulent transfers between glaciers and the atmosphere. International Association of $\mathrm{Hy}$ drological Sciences Publication 208, (Symposium at St. Petersburg 1990 Glaciers Ocean-Atmosphere Interactions), 543-549.

Müller, F. and C. M. Keeler. 1969. Errors in short-term ablation measurements on melting ice surfaces. F. Glaciol., 8 (52), 91-105.

Munro, D. S. 1989. Surface roughness and bulk heat transfer on a glacier: comparison with eddy correlation. f. Glaciol., 35 (121), 343-348.

Obukhov, A. M. 1971. Turbulence in an atmosphere with a non-uniform temperature. Boundary-Layer Meteorol., 2, 7-29.

Oerlemans, J. 1991. The mass balance of the Greenland ice sheet: sensitivity to climate change as revealed by energy-balance modelling. Holocene, 1 (1), 40-49.

Oerlemans, J. and H. F. Vugts. 1993. A meteorological experiment in the melting zone of the Greenland ice sheet. Bull. Am. Meteorol. Soc., 74 (3), $355-365$

Ohmura, A. and H. Gilgen. 1993. Re-evaluation of the global energy balance. In McBean, G. A. and M. Hantel, eds. Interactions between global climate subsystems: the Legacy of Hann. Washington, DC, American Geophysical Union, 93-110. (Geophysical Monograph 75.) (IUGG Volume 15.

Ohmura, A., H. Lang, F. Blumer and D. Grebner, eds. 1990. Glacial climate research in the Tianshan. Research report on Project Glacier No.1, 1985 1987. Zürcher Geogr. Schr. 38.

Ohmura, A. and 6 others. 1994. Energy balance for the Greenland ice sheet by observation and model computation. International Association of Hydrological Sciences Publication 223 (Symposium at Yokohama 1993-Snow and Ice Covers: Interactions with the Atmosphere and Ecosystems), 85-94.

Ohno, H., T. Ohata and K. Higuchi. 1992. The influence of humidity on the ablation of continental-type glaciers. Ann. Glaciol., 16, 107-114.

Paterson, W.S.B. 1994. The physics of glaciers. Third edition. Oxford, etc., Elsevier.

Plüss, C. and R. Mazzoni. 1994. The role of turbulent heat fluxes in the energy balance of high Alpine snow cover. Nord. Hydrol., 25 (1-2), 25-38.

Sharp, R. P. 1951. Correspondence. Melting versus evaporation in the Sierra Nevada, California. 7. Glaciol., 1 (10), 583.

Sverdrup, H. U. 1935. The ablation on Isachsen's Plateau and on the Fourteenth of July Glacier in relation to radiation and meteorological conditions. Geogr. Ann., 17 (3-4), 145-166.

Van den Broeke, M. 1996. Characteristics of the lower ablation zone of the West Greenland ice sheet for energy-balance modelling. Ann. Glaciol., 23, $160-166$.

Van de Wal, R. S. W. and A. J. Russell. 1994. A comparison of energy balance calculations, measured ablation and meltwater runoff near Sondre Stromfjord, West Greenland. Global and Planetary Change, 9(1-2), 29-38.

Wallén, C. C. 1948. Glacial-meteorological investigations on the Kårsa glacier in Swedish Lappland, 1942-1948. Geogr. Ann., 30 (3 -4), 451-672. 